\title{
Anatomy and ontogeny of the pericarp of Pterodon emarginatus Vogel (Fabaceae, Faboideae), with emphasis on secretory ducts
}

\author{
ÉLDER A.S. PAIVA ${ }^{1}$, DENISE M.T. OLIVEIRA ${ }^{1}$ and SILVIA R. MACHADO ${ }^{2}$ \\ ${ }^{1}$ Departamento de Botânica, Instituto de Ciências Biológicas, UFMG, Avenida Antonio Carlos, 6627, Pampulha \\ 31270-901 Belo Horizonte, MG, Brasil \\ ${ }^{2}$ Departamento de Botânica, Instituto de Biociências, UNESP, Caixa Postal 510, 18618-000 Botucatu, SP, Brasil \\ Manuscript received on July 6, 2007; accepted for publication on March 25, 2008; \\ presented by ALEXANDER W.A. KELLNER
}

\begin{abstract}
Discrepant and incomplete interpretations of fruits of Pterodon have been published, especially on the structural interpretation of the pericarp portion that remain attached to the seed upon dispersal. The present work clarified these doubts and analyzed ultrastructural aspects of the Pterodon emarginatus diaspores using light and transmission electron microscopes. Cell divisions are prevalent among the initial phases of development, and the subadaxial and adaxial meristems form the fibrous inner mesocarp and the endocarp composed of multi-seriate epidermis, respectively. At the median mesocarp, numerous secretory ducts differentiate between the lateral bundles, by lytic process. After lysis of the central cells and the formation of the lumen, the ducts show unistratified secretory epithelium with dense cells; oil droplets are observed on the secretory epithelium and the subadjacent tissues. At maturity, the uniseriate exocarp and the outer mesocarp slough off in an irregular fashion, leaving the diaspore composed of a papery and brittle wing linked to a seed chamber that includes the median mesocarp composed of lignified cells, bordering vascular bundles and many secretory ducts whose epithelial cells develop large vacuoles that accumulate oleoresins. The Pterodon emarginatus fruit is a cryptosamara.
\end{abstract}

Key words: Pterodon emarginatus, development, fruit, secretory duct, resin, ultrastructure.

\section{INTRODUCTION}

Pterodon Vogel is a genus of Dipteryxeae (Fabaceae, Faboideae) comprising approximately six species that are distributed throughout Brazil and Bolivia (Polhill 1981, Kirkbride et al. 2003). The genus Pterodon is distinct from other genera in the tribe by having fruits with pericarps that shed their surface layers, exposing a rigid endocarp forming a wing around a seed chamber (Polhill 1981). Almeida et al. (1998) reported that the exocarp and the mesocarp are chartaceous and brittle when mature, leaving the seed hidden within a wing-like covering of endocarp. The analyses of Barroso et al. (1999) reinforced the interpretation that the endocarp is woody and

Correspondence to: Élder Antônio Sousa Paiva E-mail: epaiva@icb.ufmg.br its form related to the anemochory observed in species of Pterodon; these authors pointed out that in this genus the exocarp ruptures in an irregular fashion, the mesocarp is not fibrous, and the endocarp demonstrates reticulated venation and resinous pockets. Kirkbride et al. (2003), however, described the fruit of Pterodon as having a wing that encircles the mesocarp unit and is more easily seen after the exfoliation of the thin exocarp; the mesocarp is thick and its surface is veined over seed chamber and inconspicuously veined on the wing; the endocarp is thin, and fibrous or spongy.

It can therefore be seen that discrepant and incomplete interpretations have been published concerning the fruit of Pterodon especially in terms of the structural descriptions of the pericarp portion that accompanies the 
seed on dispersal. This occurs because of the studies have not included ontogenetic analyses. A detailed examination of the development of the pericarp is needed to fully elucidate the complex structure of this diaspore.

The precise type of fruit of Pterodon has also been subject to controversy in the literature, and it has been classified as a dehiscent legume (Almeida et al. 1998), a cryptosamara (Barroso et al. 1999), a nutlet or legume (Kirkbride et al. 2003), and a drupaceous legume (Durigan et al. 2004).

Pterodon emarginatus Vogel is a tree species commonly known as "sucupira-branca", and it is well known as a medicinal plant in the cerrado (savanna) regions of Brazil. Secretory structures on the pericarp of $P$. emarginatus produce and accumulate resinous terpene-based substances, especially diterpenes (Fascio et al. 1976) which demonstrate biological activity as cercaricides (Mors et al. 1966) and larvicides (De Omena et al. 2006), and are used for various purposes in folk medicine (Almeida et al. 1998, Teixeira et al. 2001). According to Almeida et al. (1998), the winged endocarp is rich in extremely aromatic essential oils that are used to treat rheumatism and diabetes. Langenheim (1981) presented evidence linking diterpenes with deterrent effects against plant predators or pathogens. Although there are published works concerning the chemical nature of the secretions found in the fruits of Pterodon, it appear that no structural and ultrastructural studies have been undertaken to examine the cells involved in the secretion processes in this species.

It has generally been observed that secretory cells producing turpentine resins contain plastids and smooth endoplasmic reticulum with distinct ultrastructural characteristics. In general, these cells have dense cytoplasm with considerable amounts of endoplasmic reticulum, they are rich in leucoplasts, their plastids are usually devoid of thylakoids and, in some species, there is also an ample network of smooth endoplasmic reticulum (Dell and McComb 1978).

The present work aim to describe the structure and ontogeny of the pericarp of P. emarginatus in order to determine the proportions of pericarpial components present in the diaspore of this species. In this way the type of fruit of Pterodon will be adequately determined and the secretory structures present in the pericarp will be investigated in detail.

\section{MATERIALS AND METHODS}

Floral buds, flowers, and fruits in different stages of development were collected from individuals of Pterodon emarginatus Vogel growing in an area of cerrado (savanna) vegetation in the region near Botucatu, São Paulo State, Brazil. Fertile reference material was preserved and stored at the "Irina D. Gemtchujnicov" Herbarium (BOTU) of the Botany Department of the Biosciences Institute, at the Universidade Estadual Paulista, Campus of Botucatu, São Paulo, as collection number 23.895.

Samples for anatomical studies under light microscopy were fixed in Karnovsky solution (Karnovsky 1965), dehydrated in an ethanol series and embedded in hydroxyethyl-methacrylate Leica ${ }^{\mathrm{TM}}$ following the procedures recommended by the manufacturer. Longitudinal and transversal sections were prepared with $5 \mu \mathrm{m}$ thickness, stained with toluidine blue $0.05 \% \mathrm{pH} 4.7$ (O'Brien et al. 1964), and mounted on slides in synthetic resin.

Both fixed and fresh material was used for histochemical tests. The following tests were performed: ferric chloride solution to detect phenolic compounds (Johansen 1940); aqueous solution of ruthenium red to detect acidic polysaccharides (Johansen 1940); acidic phloroglucinol to detect lignins (Johansen 1940); Sudan black B to detect lipids (Gahan 1984); and Nadi reagent to detect essential oils (David and Carde 1964).

Transmission electron microscopic studies used fragments of the ovarian wall removed from floral buds and samples of the mesocarp and endocarp from young fruits ( 60 days after anthesis) fixed in Karnovsky solution (Karnovsky 1965) for 24 hours, post-fixed in 1\% osmium tetroxide $(0.1 \mathrm{M} \mathrm{pH} 7.2$ phosphate buffer) for two hours, dehydrated in an acetone series and subsequently embedded in araldite resin (Roland 1978). Ultra-thin sections were stained with uranyl acetate and lead citrate (Roland 1978) and viewed using a Philips EM 300 electron transmission microscope at $60 \mathrm{KV}$.

\section{RESULTS}

The ovary of Pterodon emarginatus has a single carpel and an elliptical cross section (Fig. 1). At anthesis, the inner and outer epidermises are uniseriate and the mesophyll is parenchymatous, distinguishing the uni- to biseriated hypodermis that is composed of larger and more 
cubic cells (Fig. 1). The vascularization comprises one dorsal and two ventral bundles that have few differentiated vascular elements, and numerous lateral procambial strands (Fig. 1). Phenolic compounds are observed in the outer epidermal cells and in the cell layers adjacent to them.

Cell divisions predominate after anthesis when the pericarp begins its development. A subadaxial meristem develops, and numerous periclinal cell divisions produce an inner mesocarp with many layers (Figs. 2-4). Periclinal divisions at the adaxial meristem occur later but with irregularity, giving rise to an endocarp composed of a uni- to multi-seriate layer of cells that are elongated radially and have thin walls and well developed vacuoles (Figs. 3-6); as development continues, a multiple epidermis forms (Figs. 5-6) that has more volume in its dorsal and ventral regions, in which the more internal cells project into the seminal cavity, resembling trichomes (Fig. 5). Some subabaxial periclinal divisions are still observed, and these increase from two to four cell layers the zone with phenolic compound-containing cells (Fig. 3).

Anticlinal cell divisions occur in all areas of the pericarp, especially in the dorsal, ventral, proximal and distal regions at the border of the seminal cavity; consequently, the fruit takes on a flattened appearance in transversal and longitudinal section, and the peripheral wing is produced without any participation of the endocarp (Fig. 3).

The mesocarp parenchyma located between the lateral vascular bundles during the post-anthesis phase shows small groups of cells arranged as short axial strands that have dense cytoplasm and large nuclei (Fig. 2). In the very young fruits these structures differentiate into secretory ducts through controlled lytic processes. During the formation of these ducts the epithelium is multistratified, and the lumen forms by the lysis of the central secretory cells. In a later stage, some epithelial secretory cells disaggregate (Fig. 4) and become immersed in secretions accumulated in the lumen and are subsequently broken down by lytic processes.

As these lytic processes progress, the cytoplasm of the affected cells becomes more electron dense (Fig. 7) and the plasma membrane ruptures, culminating in the liberation of their protoplasmic content. At this phase, cells in advanced stages of lysis are observed next to otherwise normal cells (Figs. 7-8). In the stages that precede lysis, paramural bodies are observed within the periplasmic space, the cell wall relaxes (Fig. 9), and small vacuoles fuse with the plasma membrane (Fig. 9) as well as with large plastids having poorly developed endomembrane systems (Fig. 8). Dispersed oil droplets and intact plastids are observed among the cellular residue after lysis (Figs. 9-10).

Starting when the fruits are still young, the secretory ducts between the lateral vascular bundles represent the greatest extension of the pericarp over the seed chamber (Fig. 11). After the lysis of the central cells and the formation of the lumen, the secretory ducts demonstrate a singly stratified epithelium (Fig. 12). Residues of the cell walls are observed only in the initial phases of lumen formation, becoming indistinct in the lumens of fully formed ducts.

Simultaneous with the radial progression of cell lysis in the secretory ducts, new cells are observed being formed within a sheath of meristematic cells surrounding the ducts. This meristematic sheath continues to add secretory cells through periclinal divisions during the growth of the pericarp (Figs. 4, 12). The lytic action, together with the activity of the meristem that delimits the secretory duct and with the lengthening of the pericarp as a whole, contributes to the significant expansion of the lumen of these structures (Figs. 11-12). These cycles of lysis and cell reposition continue until the fruit is fully expanded, so that the secretory ducts continue to expand with the growing fruit, and they demonstrate an irregular internal profile. It is important to note that these cycles of lysis and reposition are coordinated, resulting in the maintenance of a singly stratified epithelium.

During the phase of fruit lengthening, secretory cavities (Fig. 13) are also formed in the outer mesocarp, but their structure is distinct from the ducts described above. These secretory cavities are predominantly globose and their secretions are lipidic; a sheath meristem was not observed surrounding them.

The wings of nearly mature fruits are composed of the exocarp and outer mesocarp, which are parenchymatous and rich in phenolic compounds. The median and inner portions of the mesocarp are differentiated from the wings, and are composed of just a few layers of juxtaposed cells that have undergone lignification, 


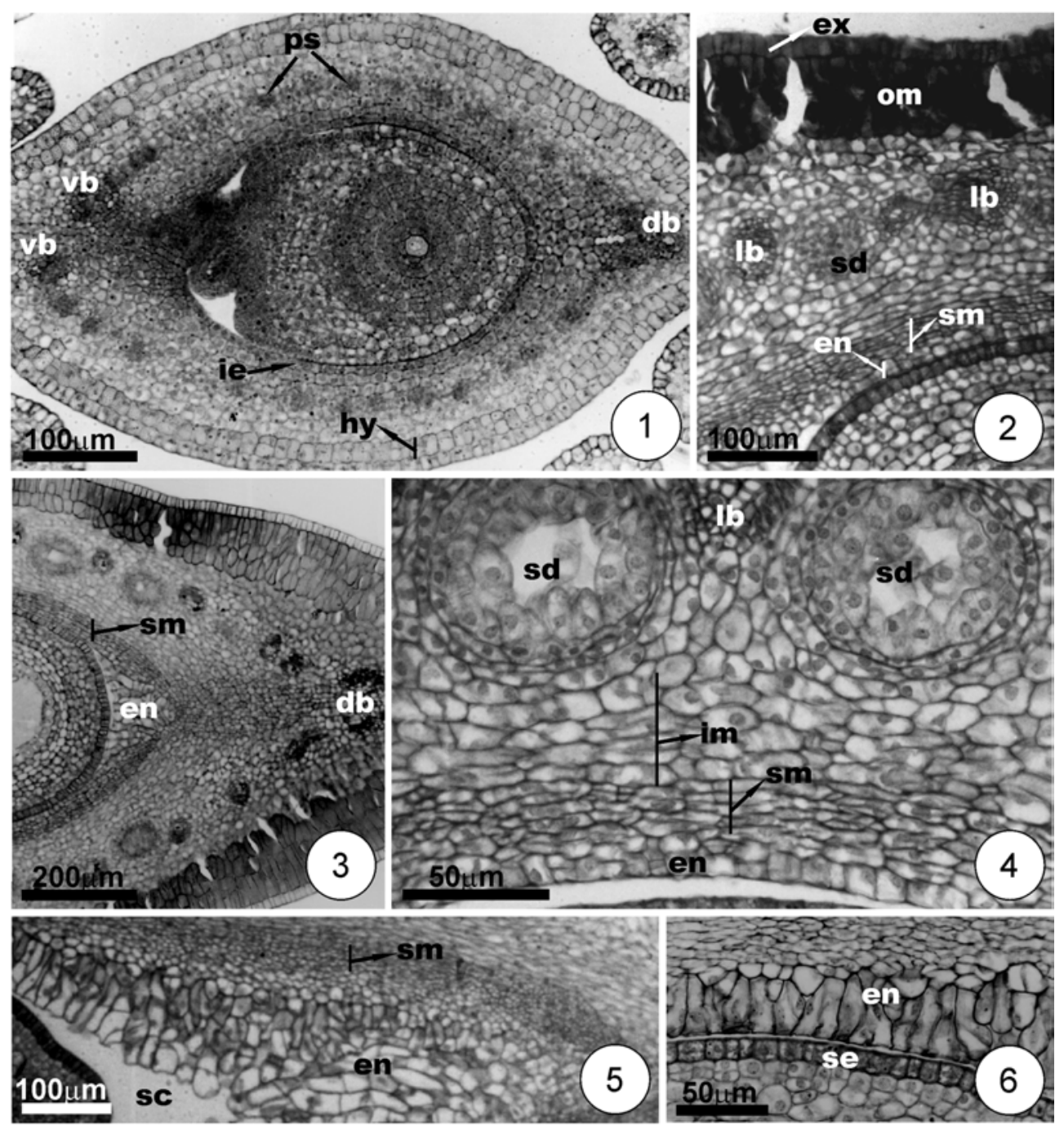

Figs. 1-6 - Transversal sections of the ovary and young fruit of Pterodon emarginatus. Fig. 1 - General view during anthesis. Fig. 2 - Detail of the post-anthesis structure, showing the subadaxial meristem. Fig. 3 - Detail of the dorsal region of the young fruit, indicating the subabaxial and adaxial periclinal divisions. Fig. 4 - Detail of the lateral region of the young pericarp, demonstrating the inner mesocarp layers produced by the still active subadaxial meristem; note the initial formation of a lumen in the secretory duct of the median mesocarp. Figs. 5-6 - Details of the dorsal and lateral regions of a more developed fruit, respectively; note the irregular thickness of the endocarp, which is thinner nearer the seed. ( $\mathrm{db}$ - dorsal bundle; en - endocarp; ex - exocarp; hy - hypodermis; ie - inner epidermis; im - inner mesocarp; lb - lateral bundle; om - outer mesocarp; ps - procambial strand; sc - seed chamber; sd - secretory duct; se - seed; sm - subadaxial meristem; vb - ventral bundle).

representing a very fibrous region into which the vascular bundles are inserted (Fig. 14).

In the more advanced development phases, the phenol-containing outer mesocarp increases by the progressive accumulation of phenolic compounds in cells towards the median mesocarp (Figs. 14-15). At maturity, the uniseriate cuticle bearing exocarp, together with the outer mesocarp, begin sloughing off in an irregu- lar fashion (Figs. 16-17). Thus both layers of phenolic compounds and all of the secretory mesocarpic cavities are lost; the shedding occurs between the outer and median mesocarp, where separation layers with small and periclinally flattened parenchyma cells can be observed (Fig. 15). The diaspore (Fig. 16) is thus composed of the median and inner mesocarp, both intensely lignified, the secretory ducts, all of the vascular bundles, and 


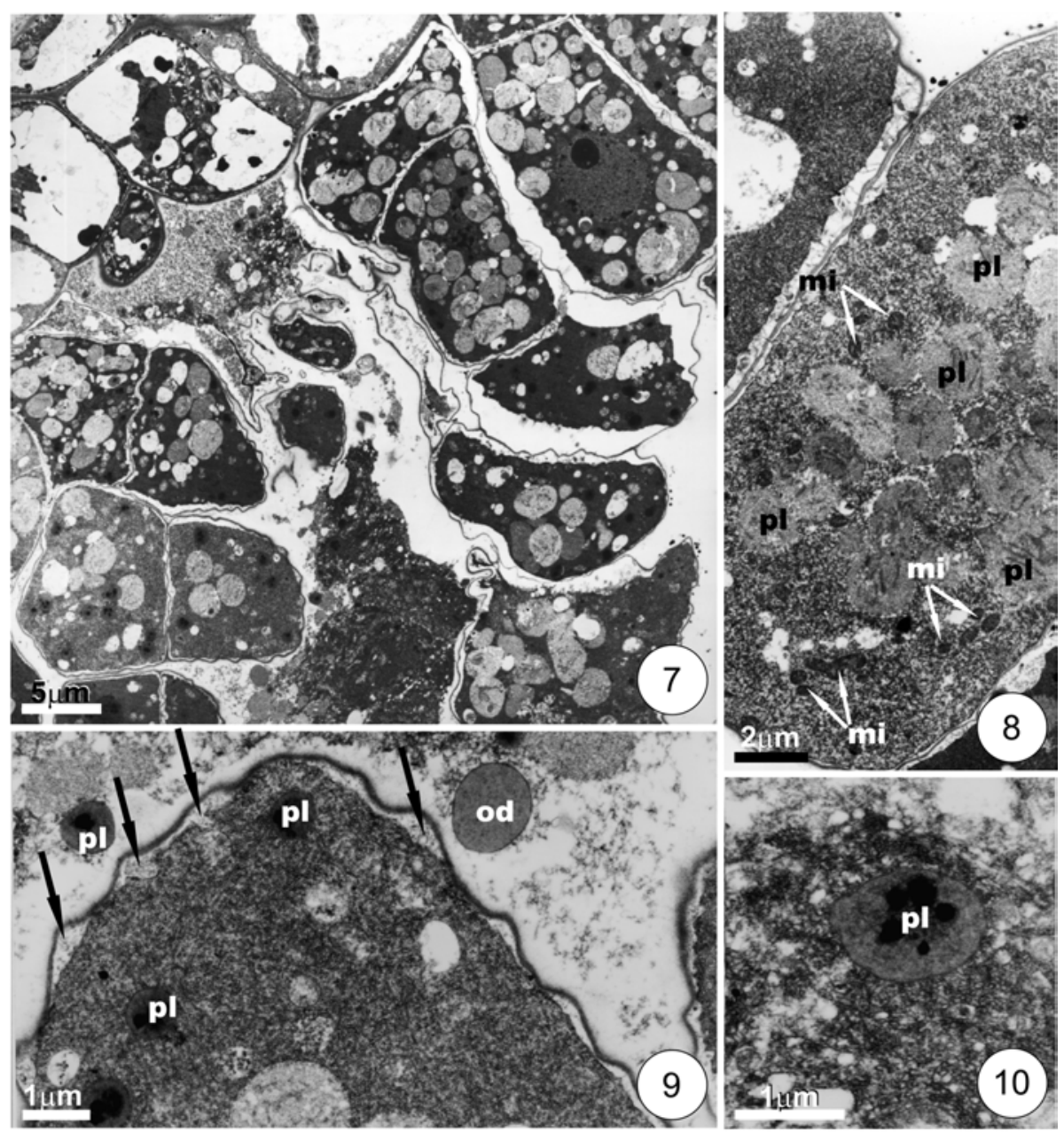

Figs. 7-10 - Ultrastructural aspects of the central cells of the secretory ducts of the fruits of Pterodon emarginatus during the formation of the lumen. Fig. 7 - General aspect of the central cells during the initial phase of lumen formation; note darkening of the protoplast and cellular lysis. Fig. 8 - Active secretory cell with dense cytoplasm, numerous mitochondria and plastids; note that the protoplast of the adjacent cells is more electron dense, indicating the terminal stage of the lytic process. Fig. 9 - Intact secretory cell delimiting a forming lumen; residues can be seen of the central cells that have already undergone lysis (arrow - paramural bodies). Fig. 10 - Detail of the cellular residues present in the lumen; note the presence of an intact plastid. ( $\mathrm{mi}$ - mitochondria; od - oil droplet; $\mathrm{pl}$ - plastid).

the parenchymatous endocarp that surrounds the seed at the seed chamber, as well as by the papery and brittle wing that is composed of the lignified median and inner mesocarp (Fig. 17).

The secretory ducts have variable individual lengths and are clearly recognizable in the mature fruit on the external face of the diaspore, with the lengthening in the axial direction (Fig. 16). They are coated only by a uni-seriate secretory epithelial layer composed of vacuolated cells (Fig. 18); in this phase the secretory processes have ceased and the ducts are full of oleoresins.
With the end of meristematic activity in the sheaths of the ducts, their cell walls thicken (Fig. 18).

The secretory phase of the secretory ducts present in the diaspores was defined as the time between the establishment of the secretory epithelium until the complete differentiation of the pericarp. During this secretory phase the cells of the secretory epithelium have dense cytoplasm (Fig. 19) and a large nuclei (Fig. 20), their mitochondria have well developed cristae, and the smooth endoplasmic reticulum is well developed (Figs. 21-23). Oil droplets were observed within the 


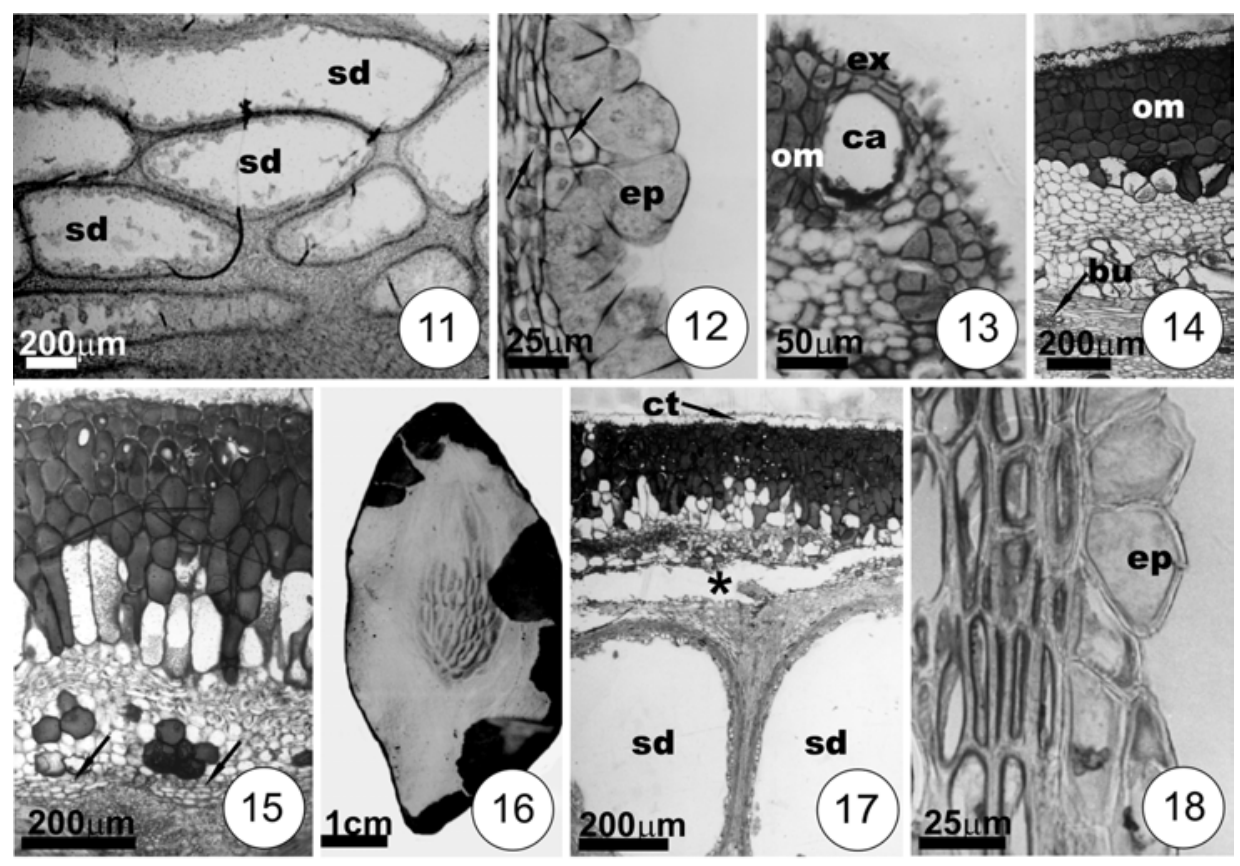

Figs. 11-18 - General view (16), longitudinal sections $(11-12,18)$ and transversal sections $(13-15,17)$ of the elongating fruit of Pterodon emarginatus (11-15), and a mature fruit (16-18). Fig. 11 - View of the median mesocarp, demonstrating the placement of the secretory ducts. Fig. 12 - Detail of the previous figure, demonstrating the singly stratified and dense secreting epithelium, as well as the meristematic sheath showing periclinal divisions (arrows). Fig. 13 - Detailed view of the cuticulate exocarp and outer mesocarp, both containing phenolic compounds; note the secretory cavities in the outer mesocarp. Fig. 14 - Lateral region of the pericarp at the end of its elongation phase; note the presence of phenolic compounds (in black) at the outer mesocarp. Fig 15 - Lateral region of the pericarp of an almost mature fruit, demonstrating a parenchymatic layer where sloughing will occur (arrows). Fig. 16 - General view of a mature fruit, with external phenol-containing and partially flaking layers exposing the wing and the seed chamber, in which the secretory ducts can be seen. Fig. 17 - Detail of the mature pericarp during the sloughing of the external portion (asterisk - separation layer). Fig. 18 - Detail of the mature secretory duct, demonstrating epithelial cells with vacuoles and the evident flattening of the cells that compose the meristematic sheath. (bu - vascular bundle; ca - secretory cavity; ct - cuticle; ep - secretory epithelium; ex - exocarp; om - outer mesocarp; sd - secretory duct).

cells of the secretory epithelium and in the subjacent cells (Figs. 20-23); some of these droplets are associated with the plastids (Fig. 22). The plastids themselves have a poorly developed endomembrane system, dense stroma, and they are found predominantly in the perinuclear region (Fig. 22). In many cases they are associated with lipid droplets that are more electron-dense than the droplets associated with the endoplasmic reticulum (Figs. 20, 22).

When the fruits reach their final size, meristematic activities ceases in the mature ducts and plastids and oil droplets are observed in the cytosol of the parenchyma cells that surround the secretory duct (Fig. 19).

With physiological maturation of the fruit, the oleoresins that have accumulated in the secretory ducts become more viscous and they remain confined within those spaces after fruit dispersal. The chemical nature of the secretions produced in the ducts and in the cavities appeared to be similar, both being lipidic. Terpenoid essential oils were identified in the secretory ducts with Nadi reagent.

\section{DISCUSSION}

The ontogenetic analyses of the fruits of Pterodon emarginatus demonstrated that none of the interpretations previously published concerning the constitution of the diaspore were completely correct. The sloughing off of the exocarp is consensual among the various authors, but a majority of them stated that the entire 


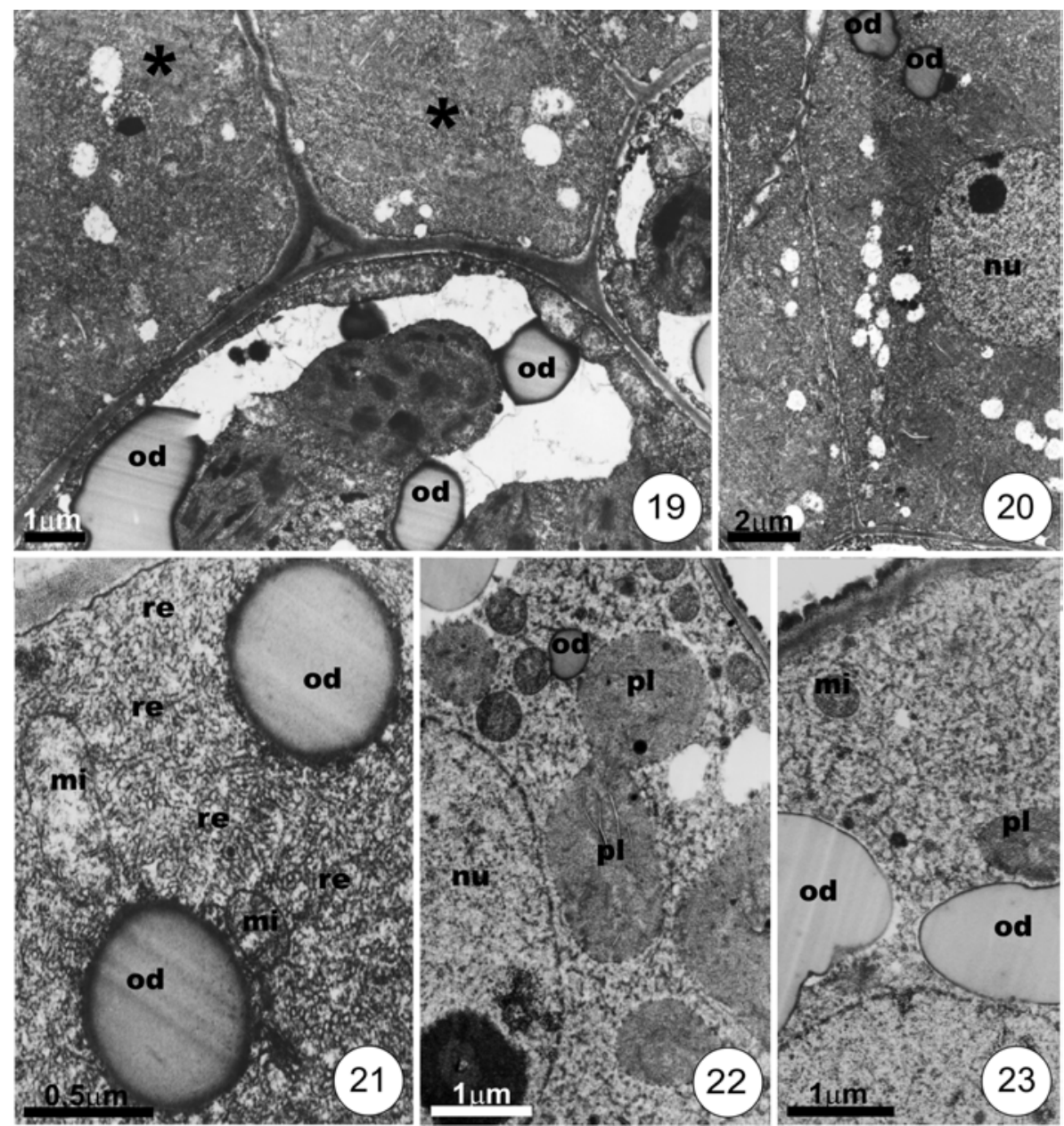

Figs. 19-23 - Ultrastructural view of the epithelial cells of the secretory ducts of a Pterodon emarginatus fruit during the secretory phase. Fig. 19 - Interface between the secretory cells with dense cytoplasm (asterisk) and the subadjacent parenchyma cells that demonstrate oil droplets and well-developed vacuoles. Fig. 20 - Secretory cell with a large nucleus and dense cytoplasm; note the presence of oil droplets in the cytosol. Fig. 21-23 - Detail of secretory cells, demonstrating the high density of the endoplasmic reticulum, presence of mitochondria with well developed cristae, dispersed oil droplets, and plastids; note in Fig. 22 the oil droplets adjacent to the plastids that demonstrate a poorly developed membrane system and dense stroma. (mi - mitochondria; nu - nucleus; od - oil droplet; $\mathrm{pl}$ - plastid).

mesocarp separates from the diaspore (Polhill 1981, Almeida et al. 1998, Barroso et al. 1999). Among the descriptions analyzed, only Kirkbride et al. (2003) recognized that the mesocarp was retained, although these authors indicated that all of the mesocarpic layers were retained, which was not supported by the observations reported here. Our observations demonstrate unequivocally that only the median and inner regions of the mesocarp participate in the constitution of the diaspore, while the outer mesocarp, including the cavities that it contains, remains attached to the exocarp.
In light of these results, the fruits of $P$. emarginatus must be considered cryptosamaras, as indicated by Barroso et al. (1999). According to these authors, partially dehiscent pericarps generate cryptosamaras when the external portion separates from the inner portion; this inner portion is indehiscent, appear as a wing-like structure and contain only a single seed. This type of fruit occurs in species of Fabaceae within the genera Amburana, Pterodon, Schizolobium, Sclerolobium, and Tachigalia (Barroso et al. 1999). Few anatomical studies have been undertaken with fruits from these genera, 
detaching the work by Pietrobom and Oliveira (2004) on Schizolobium parahyba. The pericarp section that sheds from the cryptosamara in this species is composed of the exocarp and all of the mesocarp, while the winged portion is formed only by the endocarp. As such, pericarpial vascularization can be discounted in S. parahyba, although it does compose part of the diaspore of $P$. emarginatus and is associated in this latter species with large and easily visible secretory ducts.

The fruits of $P$. emarginatus analyzed here develop in a manner typical of the family, with four well-defined stages: the ovarian wall (stage I); frequent cell divisions (stage II); extensive lengthening (stage III); and cellular differentiation, especially in terms of the lignification of the cell layers (stage IV). Meristematic activity in Fabaceae is usually associated with the adaxial meristem, as seen in Arachis hypogaea (Russell 1931), Dalbergia nigra (Paoli 1992), Inga fagifolia (Oliveira and Beltrati 1993), Tipuana tipu (Martins and Oliveira 2001), Hymenaea stigonocarpa (Paiva and Oliveira 2004), Schizolobium parahyba (Pietrobom and Oliveira 2004), and Pterocarpus violaceus (Nakamura and Oliveira 2005). An active subadaxial meristem is less frequently observed, but it was noted in the ontogeny of the pericarp of Dalbergia miscolobium, together with slight adaxial meristematic activity (D.D. Pinto and D.M.T. Oliveira, unpublished data). This is similar to that we see in P. emarginatus.

The presence of numerous secretory structures, including layers of cells containing phenolic compounds as well as cavities and secretory ducts, were particularly noticeable in the pericarp examined. Meristematic activity that gave rise to the epithelial tissue in the secretory ducts, together with the lysis of the epithelial cells, contributed to the large increase in the size of the lumens within these ducts. The contribution of the lytic processes to the growth of lumens within the secretory cavities of the Fabaceae had been reported previously by Paiva and Machado (2006) for Hymenaea stigonocarpa.

The use of the terms cavity or duct, although well defined, can sometimes be complicated by large variations in the dimensions of these structures. In the case of the fruits of $P$. emarginatus, these cavities took on forms that varied from globose to short ducts. According to Barroso et al. (1999), these structures represent resinous pockets although we chose to call them ducts due to the predominance of elongated forms.

Although the occurrence of lysis in certain secretory structures has occasionally been questioned, the coexistence of cells in different stages of lytic degradation in the secretory duct ontogeny, as seen in the present work, demonstrates that lysis is not a preparation artifact, but rather a characteristic of the process of development of these structures. The occurrence of lysis in the formation of secretory ducts is in fact very common, and has been reported for different taxonomic groups (Fahn 1979), including the Fabaceae (Paiva and Machado 2006).

The presence of intact organelles among the cellular residues resulting from the lytic processes is an indication that cell death was neither caused by necrosis, nor was it a preparation artifact (see Kerr et al. 1972, Paiva and Machado 2006), reinforcing the idea that this is a common event in the development of these structures.

The association of endoplasmic reticulum with the plastids was observed by Benayoun and Fahn (1979) in resin-secreting cells of Pinus halepensis. These authors attributed to the reticulum the function of transporting resin precursors to the outside of the cell (in addition to their role in the synthesis of these compounds). A close association between the endoplasmic reticulum and plastids is characteristic of resin-producing secretory cells (Dell and McComb 1978, Fahn 1988, Carmello et al. 1995). According Langenheim (2003) a central role for the endoplasmic reticulum in transporting terpenoid resin components from intracellular sites of synthesis into the lumen of an endogenous secretory structure had long been assumed because endoplasmic reticulum can fuse with membranes of other organelles and form vesicles that move trough the cell to the plasma membrane.

It is probable that the plastids observed in the secretory cells are involved in the biosynthesis of the terpenoid secretions that accumulate in the lumens of the secretory structures, as these organelles are known to produce those compounds (Dell and McComb 1978, Lichtenthaler et al. 1997). The presence of a well developed smooth endoplasmic reticulum is an indication of lipid synthesis, as is the presence of plastids with poorly developed endomembrane systems. Based on the differences between the electron-density of the lipid droplets associated with the plastids and those associated with 
the endoplasmic reticulum, it is possible to infer that these organelles produce distinctly different compounds, which are later brought together to form the secretions. According to Turner et al. (1999), the metabolism of terpenes involves different subcellular compartments.

Disperse oil droplets can be observed near the plasma membrane, which suggests the fusion of these droplets with the membrane and a subsequent liberation of their contents into the duct lumen, similar to the processes observed in secretory cavities that synthesize resins (see Paiva and Machado 2006).

Secretions found in the secretory ducts of the fruits of $P$. emarginatus are initially produced by holocrine processes, as the lysis of secretory cells and their incorporation into the secretory product by ecrine processes has been observed. After the expansion of the fruit, only the ecrine processes persist, lasting until the end of the secretory phase. This secretion pattern has also been observed by Paiva and Machado (2006) in the resinous secretory cavities of Hymenaea stigonocarpa (Fabaceae).

The distinction between resins and oleoresins is based on the proportions of their volatile and non-volatile terpene content. According to Langenheim (2003), oleoresins are fluid terpene resins that have a high ratio of volatile to non-volatile terpenes. Resins or terpene oils have an important role in plant defenses against herbivory as they exhibit a toxic or deterrent effects on insects and mammals (Gershenzon and Croteau 1991). According to Dell and McComb (1978), one of the most probable functions of the resins produced and stored in plants is protection against insect predation.

The increase in the viscosity of the oleoresins that accumulate in the secretory ducts seems to be the result of the loss of the more volatile compounds during dehydration of the pericarp, similar to that reported by Paiva and Machado (2006) for the resins present in the leaves of $H$. stigonocarpa. According to Langenheim et al. (1978), the barrier formed by resins in the pericarp region seems to act in protecting the seeds against predation by herbivores.

The present work determined that the developmental patterns of the outer mesocarpic secretory cavities differ from those seen in secretory ducts, although additional studies will be necessary in order to more precisely define them.

\section{ACKNOWLEDGMENTS}

The authors thank to Conselho Nacional de Desenvolvimento Científico e Tecnológico $(\mathrm{CNPq})$ for research grants of D.M.T. Oliveira and S.R. Machado, and to Fundação de Amparo à Pesquisa do Estado de São Paulo (FAPESP), Program BIOTA (Proc. 00/12469-3), for financial support.

\section{RESUMO}

Interpretações discrepantes e incompletas têm sido conferidas ao fruto de Pterodon, especialmente no que tange à determinação estrutural da porção pericárpica que acompanha a semente na dispersão. Assim, com o objetivo de dirimir tais dúvidas e analisar a organização ultra-estrutural das estruturas secretoras presentes no diásporo de Pterodon emarginatus, realizaram-se estudos convencionais aos microscópios de luz e eletrônico de transmissão. Nas fases iniciais de desenvolvimento do fruto, prevalecem divisões celulares; pela ação do meristema subadaxial e do adaxial, formam-se, respectivamente, o mesocarpo interno fibroso e o endocarpo composto por epiderme multisseriada. No mesocarpo mediano, entre os feixes vasculares laterais, diferenciam-se numerosos ductos secretores lisígenos. Após a lise das células centrais e formação do lume, os ductos apresentam epitélio secretor uniestratificado, com células densas; gotas de óleo são observadas no epitélio secretor e tecido subjacente. Na maturidade, o exocarpo unisseriado e o mesocarpo externo, ambos fenólicos, descamam irregularmente, sendo o diásporo constituído pela ala papirácea e quebradiça, ligada ao núcleo seminífero que abrange o mesocarpo mediano de células lignificadas, margeando feixes vasculares e muitos ductos secretores, que apresentam acúmulo de oleorresina e cujas células epiteliais tornam-se vacuoladas. $\mathrm{O}$ fruto de Pterodon emarginatus é, portanto, uma criptossâmara.

Palavras-chave: Pterodon emarginatus, desenvolvimento, fruto, ducto secretor, resina, ultra-estrutura.

\section{REFERENCES}

Almeida SP, Proença CEB, Sano SM and Ribeiro JF. 1998. Cerrado: espécies vegetais úteis. Planaltina: EMBRAPA-CPAC, 464 p.

Barroso GM, Morim MP, Peixoto AL and Ichaso CLF. 1999. Frutos e sementes. Morfologia aplicada à sistemática de dicotiledôneas. Viçosa: Editora UFV, 443 p.

BENAYOUN J AND FAHN A. 1979. Intracellular transport and elimination of resin from the epithelial duct-cells of Pinus halepensis. Ann Bot 43: 179-181. 
Carmello SM, Machado SR ANd Gregorio EA. 1995. Ultrastructural aspects of the development in Lithraea molleoides (Vell.) Engl. (Anacardiaceae). Rev Bras Bot 18: 95-103.

DAVID R AND CARDE JP. 1964. Coloration différentielle des inclusions lipidique et terpeniques des pseudophylles du pine maritime au moyen du reactif Nadi. CR Acad Sci, Paris, Série D 258: 1338-1340.

De Omena MC, Bento ES, De Paula Je and SanTANA AEG. 2006. Larvicidal diterpenes from Pterodon polygalaeflorus. Vect Born Zoon Dis 6: 216-222.

Dell B AND MCCOMB JA. 1978. Plant resins - their formation, secretion and possible functions. Adv Bot Res 6: 276-316.

Durigan G, BAitello JB, Franco GADC AND SiqueIRA MF. 2004. Plantas do cerrado paulista. Imagens de uma paisagem ameaçada. São Paulo: Páginas \& Letras Editora e Gráfica, 475 p.

FAHN A. 1979. Secretory tissues in plants. New York: Academic Press, 302 p.

FAHN A. 1988. Secretory tissues in vascular plants. New Phytol 108: 229-257.

Fascio M, Mors WB, Gilbert B, Mahajan JR, Monteiro MB, Santos Filho D AND Vichnewski W. 1976. Diterpenoids furans from Pterodon species. Phytochem. 15: 201-203.

GAHAN PB. 1984. Plant Histochemistry and Cytochemistry: an Introduction. New York, Academic Press, $301 \mathrm{p}$.

Gershenzon J And Croteau R. 1991. Terpenoids. In: Rosenthal GA AND Berenbaum MR (Eds), Herbivores: their interactions with secondary plant metabolites, vol. 1, $2^{\text {nd }}$ ed., San Diego: Academic Press, p. 165-219.

JOHANSEN DA. 1940. Plant microtechnique. New York: McGraw-Hill, 523 p.

KARNOVSKY MJ. 1965. A formaldehyde-glutaraldehyde fixative of high osmolality for use in electron microscopy. J Cell Biol 27: 137A-138A.

Kerr JER, Wyllie AH AND CURRIE AR. 1972. Apoptosis a basic biological phenomenon with eide-ranging implications in tissue kinetics. - British J Cancer 26: 239-257.

KiRKBRIDE JR JH, GUNN CR AND WeItZMAn AL. 2003. Fruits and seeds of genera in subfamily Faboideae (Fabaceae). Tech Bull U S Dep Agric 1890: 1-1212.

LANGENHEIM JH. 1981. Terpenoids in the Leguminosae. In: Polhill RM AND RAVEN PH (Eds), Advances in legume systematic. Part 2, Kew: R Bot Gard, p. 627-655.

Langenheim JH. 2003. Plant Resins. Cambridge: Timber Press, $586 \mathrm{p}$.
LANGENHEIM JH, STUBblebine WH, LinCOLN DE AND Foster CE. 1978. Implications of variation in resin composition among organs, tissues and populations in the tropical legume Hymenaea. Bioch Syst and Ecol 6: 299-313.

Lichtenthaler HK, Schwender J, Disch A And ROHMER M. 1997. Biosynthesis of isoprenoids in higher plant chloroplasts proceeds via a mevalonate-independent pathway. FEBS Letters 400: 271-274.

Martins MAG AND Oliveira DMT. 2001. Morfo-anatomia e ontogênese do fruto e da semente de Tipuana tipu (Benth.) O. Kuntze (Fabaceae: Faboideae). Rev Bras Bot 24: 109-121.

Mors WB, Pellegrino J and Santos Filho MF. 1966. Ação profilática do óleo dos frutos de sucupira branca, Pterodon pubescens Benth., contra a infecção pelo Schistosoma mansoni. An Acad Bras Cienc 38: 325-330.

NAKAMURA AT AND Oliveira DMT. 2005. Morfoanatomia e ontogênese da sâmara de Pterocarpus violaceus Vogel (Fabaceae: Faboideae). Rev Bras Bot 28: 375-387.

O’Brien TP, Feder N ANd McCully ME. 1964. Polychromatic staining of plant cell walls by toluidine blue $\mathrm{O}$. Protoplasma 59: 368-373.

Oliveira DMT ANd Beltrati CM. 1993. Aspectos anatômicos dos frutos e sementes em desenvolvimento de Inga fagifolia (Fabaceae: Mimosoideae). Rev Bras Biol 53: 625-636.

PaIVA EAS AND Machado SR. 2006. Structural and ultrastructural aspects of ontogenesis and differentiation of resin secretory cavities in Hymenaea stigonocarpa (Fabaceae-Caesalpinioideae) leaves. Nord J Bot 24: 423-431.

PAIVA EAS AND OliveIRA DMT. 2004. Ontogenesis of the fruit pulp layer of Hymenaea stigonocarpa Mart. ex Hayne (Fabaceae: Caesalpinioideae). Aust J Bot 52: 677-683.

PAOLI AAS. 1992. Desenvolvimento morfo-antatômico do fruto de Dalbergia nigra (Vell.) Fr. All. (Leg.-Faboideae). Acta Bot Bras 6: 65-72.

Pietrobom RCV AND Oliveira DMT. 2004. Morfoanatomia e ontogênese do pericarpo de Schizolobium parahyba (Vell.) Blake (Fabaceae, Caesalpinioideae). Rev Bras Bot 27: 767-779.

Polhill JH. 1981. Dipteryxeae. In: Polhill RM AND RAVEn PH (Eds.), Advances in legume systematic. Part 1, Kew: R Bot Gard, p. 231-232.

RolAND AM. 1978. General preparations and staining of thin sections. In: HALL JL (Ed), Electron Microscopy and Cytochemistry of Plant Cells. New York: Elsevier, p. $1-62$. 
RUSSELl MW. 1931. Étude organogénique du fruit de l'Arachide. Rev Bot Appl et d'Agric Tropic 11: 885-890.

Teixeira Al, Belinelo VJ, Stefani GM, Reis GT, Ferreira-Alves DL AND Piló-Veloso D. 2001. Síntese de amidas derivadas do ácido $6 \alpha, 7 \beta$-Di-hidroxivouacapan-17 $\beta$-óico isolado dos frutos de Pterodon polygalaeflorus Benth (Leguminosae). Rev Bras Plantas Med 3: 37-44.
Turner G, Gershenzon J, Nielson EE, Froehlich JE AND CROTEAU R. 1999. Limonene synthase, the enzime responsible for monoterpene biosynthesis in peppermint, is localized to leucoplasts of oil gland cells. Plant Physiol 120: 879-886. 